\title{
РЕГУЛЯЦІЯ ПОВЕДІНКИ ОСОБИСТОСТІ СИМВОЛОМ: ТЕОРЕТИКО-МЕТОДОЛОГІЧНИЙ АСПЕКТ
}

\section{Хміляр Олег Федорович}

Кандидат психологічних наук, дочент, начальник кафедри суспільних наук Національного університету оборони Украӥни імені Івана Черняховського (Київ, Україна)

\begin{abstract}
Анотація. Розглянуто теоретико-методологічні основи регуляції поведінки особистості за допомогою символу. Показано, щуо символ, регулюючи поведінку особистості, спрямовує ї̈ у бажаному напрямку, оскільки впливає на прочеси мислення. Висвітлено як завдяки символові особистість актуалізує смисли, які не усвідомлені в раџіонально знакових формах.

Розкрито роль символу як функиії поведінки, щчо дає змогу особистості всебічно пізнати себе. Встановлено, щуо символ, регулюючи поведінку, стає ї̈ відображенням, законом, принципом $i$ моделлю дії особистості.
\end{abstract}

Ключові слова: символ, особистість, регулятор, дія, символічна регуляція поведінки.

Постановка проблеми. У розвитку основних напрямків та галузей психологічної науки чітко простежується тенденція вивчення людини в її суб’єктних якостях, властивостях та умовах саморозвитку у побудові своєї поведінки. Суб'єктне буття людини, досить складне й багатоаспектне, забезпечується системою людської психіки й реалізовується в різноманітних формах. Одним із найбільш загальних проявів суб'єктності людини є ії довільна усвідомлена активність, за допомогою якої реалізовується все різноманіття відносин людини зі світом речей, людей, умовами сере- довища, соціальних явищ. При цьому символічна регуляція усвідомленої активності поведінки є найбільш загальною функцією цілісної психіки людини. У процесах символічної регуляції поведінки проявляється єдність психіки у розгляді ії можливостей, функцій, процесів та здатностей $[8 ; 12]$.

За С. Л. Рубінштейном, регулювати поведінку особистості - означає насамперед впорядковувати, налагоджувати й розвивати іiі дії відповідно до певних правил та норм. Оскільки поведінка особистості включена в широку систему соціальної регуляції, іiі функціями є: 
формування, оцінювання, підтримка, захист i відтворення необхідних суб'єктам регулювання норм, правил, механізмів, засобів, що забезпечують існування взаємодії, спілкування, діяльності особистості як члена суспільства [12]. Виходячи з цього мета статті полягає у розкритті теоретико-методологічних основ регуляції поведінки особистості за допомогою символу.

Аналіз останніх досліджень і публікацій. Регуляція поведінки особистості - завдання надзвичайної складності, що передбачає цілеспрямоване використання доцільних дій, спрямованих на досягнення осмислених цілей. Одну і ту ж дію залежно від передбачення іiі результатів чи продукту дії, смислу завдання спрямовують і корегують мінімум п'ять самостійних регуляторів: символ, думка, образ, почуття та почування [8]. Дослідження символічної регуляції поведінки особистості передбачає уточнення понять регулячія, дія, образ, які виражаються в поведінці.

Основні принципи регулювання, які лежать в основі поведінки особистості, сформульовані К. Бернаром у положенні про стійкість внутрішнього середовища, згідно з яким організм людини здатен підтримувати в певних межах свої життєво важливі функції у відповідь на впливи зовнішнього середовища. Логічним наслідком принципу “життєвого кола" К. Бернара є теорія гомеостазу У. Кеннона, в якій розкрито суть механізмів, що підтримують постійність внутрішнього середовища організму.

Працями I. М. Сєченова покладено початок послідовного формування уявлень про регуляторний характер перебігу різноманітних психічних явищ [13]. Рефлекторне розуміння психічного підтверджено у працях I. П. Павлова. Важливі висновки багаторічного досвіду досліджень закономірностей вищої нервової діяльності відображені в одному 3 висловлювань І. П. Павлова: “Людина, звичайна система, яка підкоряється неминучим та єдиним для всієї природи законам; але система, яка в горизонті нашого сучасного наукового бачення - єдина 3 найвищим саморегулюванням” [11, с. 394]. Далі цю думку конкретизовано: "ця система... сама себе підкріплює, відновлює, спрямовує і навіть змагається сама iз собою" [11, с. 395]. Учений підкреслює роль великих півкуль головного мозку не тільки як верховного органу системи регуляції, а й як постійного контролера виконавчих функцій організму.

Творчим розвитком наукових поглядів I. М. Сєченова та I. П. Павлова є створена П. К. Анохіним теорія функціональної системи, в межах якої розкрито питання регуляції як всезагального закону діяльності організму. Всі функціональні системи, вроджені чи динамічні, сформовані в конкретній ситуації, мають, на думку П. К. Анохіна, одну й ту ж “операційну архітектоніку”. Їх ключовими механізмами є аферентаційний синтез, прийняття рішення й акцептор дії, функціонування 
яких становить “золоте правило регуляції” [1].

Велика заслуга в поставленні й розкритті важливих аспектів проблем психічної регуляції належить науковій школі В. М. Бехтерєва, у працях якого, а також його учнів i послідовників О. Ф. Лазурського, М. Я. Басова, В. М. Мясищева, Б. Г. Ананьєва та інших міститься немало оригінальних думок, теоретичних та експериментальних розробок цієї проблеми. Так, В. М. Бехтерєв розглядає роботу головного мозку як “складну організацію контурів регулювання численними ланками, що включають об'єкти регулювання, вимірювальні та виконавські пристрої, механізми зворотного зв'язку, які забезпечують постійність регульованої величини" [3, с. 85].

Виклад основного матеріалу. Як зазначає О. В. Соловйов, важлива роль у функціонуванні складних динамічних систем різноманітної природи належить процесам регулювання. Як регулювання слід розуміти приведення будь-чого у відповідність до установлених норм і правил. Процес регулювання розглянуто як порівняння регульованої величини із заданим значенням, а у разі відхилення від заданого значення в об'єкт регулювання надходить вплив, який відтворює регулюючу величину. Таким чином, процес регулювання обов'язково передбачає наявність регульованого об'єкта та регулюючої системи (регулятора) [14]. Регулятор складається із вимірювального пристрою, в якому заданий стан системи порівнюється з реальним станом ре- гульованого органу, завдяки якому може бути змінений у разі потреби стан, який підлягає регулюванню.

Найгрунтовніше, проблему психічної регуляції поведінки особистості усвідомив М. О. Бернштейн, який, розвиваючи сечєновські надбання, створив концепцію фізіології активності, згідно з якою живий людський рух, активно впливає на середовище і перетворює його відповідно до своєї мети [2]. Це новий рівень взаємовідносин організму із зовнішнім середовищем, зміни в якому переносяться не на пасивний відображувач, а налаштовують і перебудовують активно працюючі системи, накладаючи обмеження на організуючу діяльність мозку. Розглядаючи морфогенез нервової системи, учений стверджує, що цей процес відбувається за типом нарощування філогенетичних новоутворень $є$ своєрідним перетином, у якому відображена вся історія цих утворень.

Зокрема М. О. Бернштейн визначає послідовність морфогенезу форм регуляції дій i поведінки людини відповідно до фізіологічних субстратів нервової системи. Так, палеокінетичні регуляції, здійснювані таламопірамідними утвореннями, стосуються переважно метаболізму - перетворення речовин та енергії, які становлять основу життя людини; регуляція просторового поля, здійснювана пірамідно-стріальними утвореннями, містить два окремих регулятори: простір у схемі тіла, що регулюється стріальними структурами, які 
належать до екстрапірамідної системи, і простір дій - пірамідну систему, що підлягає контролю кортикальних утворень; регуляція предметних, смислових дій, здійснювана тім'янопремоторними утвореннями; регулятори вищих кортикальних рівнів, що забезпечують символічну координацію рухів і дій особистості та поведінки в цілому [2, с. 101].

Характеризуючи зазначені регулятори поведінки, слід враховувати, що кожен з них має локалізацію у субстратах нервової системи, власну аферентацію, що забезпечує точність відповідних рухів і дій особистості; властивості рухів, регульованих цим утворенням; кожне з утворень $є$ фоновим, що зумовлює більш високе утворення; кожний регулятор несе у собі дисфункцію, а також елементи патології.

На основі досліджень мозкової організації поведінкових процесів М. О. Бернштейна можемо зазначити, що для назви предмета достатньо дії мозкових структур нижчого й генетично більш раннього рівня “D”, відповідального за формування предметних дій, - i лише для побудови семантичних і синтаксичних мовленнєво-поведінкових конструкцій, регульованих службовими словами-операторами, необхідним є вихід на найвищий рівень мислення - рівень “Е”, який відповідальний за організацію символічних дій і поведінки особистості [2].

За В. В. Клименком регулятор є образом внутрішньої мети особистості, живим пристроєм зі спеціалізованими функціональними структурами - гештальтами, у яких записана, зберігається й передається спадкова інформація для життя і функціонування живої істоти у стахостичній взаємодії з довкіллям [8, с. 49]. 3 цієї точки зору психіка особистості $€$ своєрідним перетворювачем інформації, за допомогою якого вона відображає властивості і структуру предметів та явищ довкілля, що $є$ предметом регуляції; проектує рухи думки, почуттів, уяви та інші психічні явища; регулює дії, активність і поведінку в цілому в середовищі буття.

У теорії психічного відображення B. В. Клименка існує положення, згідно 3 яким мірою адекватності інформації про систему рухів думки, почуттів, уяви, дій є відповідність результатів дії меті або бажанню, що побудовані на основі цієї інформації. Важливими для розуміння регуляторної функції інформації є такі твердження: а) інформація - це позначення змісту, отриманого 3 довкілля, а також міра усунення невизначеності відображеного предмета; б) регулювання й оцінювання дії та іï продуктів передбачаються ще до іiї початку на основі прогностичної інформації $[8]$.

Психічна система особистості сприймає розмаїтість впливів зсередини тіла або 3 довкілля; зменшує розмаїтість усуненням або “погашенням” шкідливих впливів; має більшу розмаїтість порівняно з розмаїтістю шкідливих впливів, що нею усуваються. 
Як зазначає В. В. Клименко, регулятор у структурі кожного з механізмів підтримує незмінність психічних явищ або станів, змінює їх за певними законами - відповідно до еталону, мірки чи взірця. Регулятор є нормою дії, правилом, що визначає напрям розвитку психічного явища, надає планомірності й виправляє помилки під час дії. Таким чином, peгулятор - функціональний орган, в якому інформація виконує в діях особистості функції живого відображення предметів та явищ. Роль психічної регуляції полягає в обмеженні розмаїтості впливів чи реакцій протидій на ці впливи. При цьому регулятор обмежує розмаїтість не всіх довільних впливів, а лише несприятливих для комфортного стану особистості.

Отже, згідно з В. В. Клименком орган, що усуває руйнівні та не допускає шкідливих впливів, є регулятором (регулюючою системою) поведінки особистості. Однак, як далі зазначає учений, це не означає, що інформація, яку має особистість, завжди безпосередньо пов'язана 3 ii поведінкою. Первинним джерелом інформації є почування - система чуттєвої інформації, доступна для сприйняття і практичної дії особистості в системі "Я" “не-Я”. Із предметом особистість пов'язана двояким чуттєвим зв'язком, ширшим, ніж однобічний зв'язок, і доступним сприйняттю i спостереженню.

3 поведінкою особистості безпосередньо пов'язана чуттєво-інтуїтивна інформація, яка надходить від предметів і дій. Інша частина інформації - дискурсивно-логічна - теоретична, пов'язана 3 поведінкою побічно, через трансформацію знакових систем - знань про себе, предмети дій, довкілля. Дослідження відносин під час дії дали змогу виявили причини, що породжують в особистості стан непевної поведінки. Переважно вони спричинені невмінням переборювати інформаційні, енергетичні надмірності та механізми психічного відображення [8, с. 47].

Особлива роль у регуляції поведінки особистості належить символові як словесній моделі породження дії та поведінки особистості, що стає ії дійсним буттям і формує стан душевного піднесення. Людина в дії “роздвоюється”: одна іiї частина регулює рухи, а друга спостерігає за правильністю дії та забезпечує випереджувальні рухи в дії. Така діалогічна активність забезпечує порівняння, оцінювання та судження відповідності бажаного і дійсного в дії.

На основі теорії В. В. Клименка символічні способи регуляції поведінки особистості визначаються потенціалом праксису, пізнавальним ставленням до самого себе і довкілля, опануванням дій, здатних втілювати образи, думки та почуття у форми предметів чи знакових систем [8, с. 47]. Символ, регулюючи дії та поведінку особистості, спрямовує її у бажаному напрямі, оскільки живий рух чи дія $є$ не стільки переміщенням у просторі, часі та силовому полі своєї дії, скільки оволодінням 
своїми почуттями, думками, поняттям простору, часу, силового поля дій, із підпорядкуванням їх наперед заданій меті.

Символічна регуляція поведінки забезпечує орієнтаційно-розпізнавальну роль ще незасвоєного, перетворюючи неусвідомлюване на надбання мислення, почуттів та уяви. За таких умов символ є планом, проектом і програмою, заданим людині для ефективного регулювання своїми рухами думки, почуттів та уяви. Завдяки символу особистість виявляє й актуалізує смисли, не об'єктивовані і не усвідомлені в раціонально знакових формах. Символ - універсальний засіб регуляції духовнопрактичного досвіду, медіатор відношень людини зі світом. 3 огляду на це вважаємо, що у структурі психіки необхідно виділити особливий компонент, в якому б домінували активні символічні утворення. які проявляючись у символі, заряджені неусвідомлюваними установками, глибинними особистими смислами та мотивами.

Як бачимо, символ - це регулятор, що утворюється на матеріалі знакових систем, які є засобом спілкування між людьми. Символічна регуляція вносить у дії людини порядок, систему, спрямовує поведінку людини в діапазоні “незграбність-гармонійність", ведучи іiі до вершин досконалості. Символ-регулятор особливий образ, в якому почуттєво започаткований потяг до порівняння образу, який він містить, із життям. Освоївши інформацію образу-символу, особистість стає здатною само- стійно конструювати та розробляти систему дій розуму і контролювати їх розвиток без перенавчання. Натомість наявність в образі псевдоінформації програмує в системі дій людини дефект, і вона виростає 3 неповноцінним механізмом.

Як зазначає В.В. Клименко, символ, регулюючи поведінку особистості, впливає не стільки на почуття та уяву, скільки на мислення, на його проникливість, натякаючи на можливість, яка існує потенційно, але ще не має чіткого вираження.

Згідно 3 А. Валлоном символічна регуляція дає змогу особистості не лише пізнавати властивості предметного світу, а й використовувати їх силу для зміни самого предмета й поведінки в цілому у нові форми для задоволення життєвих потреб. Сама думка із дій особистості виростає, розвивається й набуває найвищого рівня досконалості. "Від дії до думки й від думки до дії” - такий шлях символічної регуляції поведінки у валлонівській теорії пізнання, основу якої становить уявлення [4, с. 17]. Проблема уявлень як одна 3 основних проблем регуляції поведінки і дії особистості тісно пов'язана з описанням, порівнянням, ідентифікацією, визначенням і поясненням реальності. Генеза уявлення, як і наслідування, перебуває, згідно з А. Валлоном, у предметних діях людини й розвивається в пізнавальних процесах.

У символічній регуляції поведінки особистості важливу роль відіграють описові дії 
та чуттєво-інтуїтивні символи, які сприяють розвитку уявлень. Утворення самого образу без конкретних дій і ситуацій неможливе, оскільки завдяки діям до складу образу входять певні сторони відображуваного об'єкта чи явища. Особистість прагне відображати те, що відбувається в іiі розумовій діяльності на основі образів. Так, описовий жест дитини, як зазначає А. Валлон, виражає дію чи інші якості поведінки об'єкта, якого немає в цей момент, оскільки дитина ще не здатна повністю й виразно відображати свої враження у словах [4].

Регуляція поведінки особистості завжди спрямована на конкретний результат. Водночас, за даними С.Л. Рубінштейна, регуляція може дати різні результати, деякі з них можуть мимовільно й невимушено виходити 3 неї, а оскільки поведінка особистості є соціальною, іï результати мають безпосередньо усвідомлену мету. Свідома, цілеспрямована поведінка особистості є іï специфічною рисою. Якою б істотною не була мета, однієї іiі для визначення поведінки недостатньо. Для реалізації мети потрібно врахувати ряд умов, в яких iї слід реалізовувати. Співвідношення мети 3 умовами визначає завдання, яке має бути вирішене дією. Цілеспрямована дія формує поведінку особистості [12].

Отже, поведінкою, спрямованою на той чи інший предмет чи вагомий результат, людина неминуче взаємодіє 3 іншою людиною, впливає на інших людей, на свої взаємини 3 ними. За С. Л. Рубінштейном поведінку особистості регулюють дії різних видів (рефлекторні, інстинктивні, імпульсивні, символічні, вольові) і рівнів. Регулюючи поведінку, особистість втілює свій запас енергопотенціалу в предмет дії, опрацьовує інформацію, збільшуючи потужність іiі механізму. Завершена дія збагачує поведінку особистості досвідом вирішення завдання. 3 цього випливає, що процес дії - це програмування поведінки особистості. Створення образу майбутньої поведінки починається після завершення дії, а інформація, яка в ній здобута, переводиться в довгострокову пам'ять для доповнення елементами, яких особистості бракувало в минулому, а також реконструкції цілісності поведінки. При цьому робота пам'яті відбувається без контролю з боку свідомості й регулюється лише енергетикою особистості: чим вона більша, тим швидше відновлюється витрачена енергія, сильніші почуття і глибше мислення, тим конструктивніша поведінка особистості [12].

На думку О. Р. Малхазова, регуляція поведінки особистості є найважливішим, ключовим етапом, що визначає цілі, зумовлює інтенсивність і тривалість асоційованих емоційних станів з об'єктом уваги. Утворення мети дії пов'язане із прийняттям рішення як заключним етапом аферентного синтезу, на яке впливають як провідні, так і ситуативні емоції [9]. Постійне порівняння результатів поведінки з образом, створеним програмуючим меха- 
нізмом, та оновлення схем програмування зумовлюють цілеспрямованість поведінки особистості.

Згідно з теорією О. М. Малхазова регуляція поведінки особистості відбувається в шість етапів. На першому етапі провідну роль відіграє механізм формування ставлення особистості до ситуації, що виникла; на другому проводиться регуляція механізму, який задає i формує образ потрібного майбутнього; на третьому - запускається зіставний механізм, коли за допомогою орієнтувально-пошукових дій зіставляється образ потрібного майбутнього з наявними образами виконання дії; на четвертому - домінує механізм програмування, який будує та уточнює програму дії-образу поведінки; на n'ятому - домінує механізм зіставлення, у функціонуванні якого значну роль відіграє орієнтувально-пошукова поведінка; на шостому - домінує механізм формування ставлення особистості до результату поведінки і зіставного механізму.

Як бачимо, на кожному з шести етапів конкретного акту регуляції поведінки відбувається свій цикл послідовної актуалізації механізмів формування ставлення особистості до ситуації - механізму, що задає, механізму, який програмує, механізму, який зіставляє, та механізму корекцій. Основу цих механізмів складає орієнтувально-пошукова поведінка, яка кожного разу оновлюється у випадку виявлення відмінностей між завданням і результатом дії на кожному з етапів.
Важливу роль у забезпеченні результативності орієнтувально-пошукової поведінки О. Р. Малхазов відводить увазі - психічній дії, спрямованій на формування образу, думки й інших утворень, які в певний момент є значущими у психіці особистості. Як окремий, самостійний акт, увага виділяється, коли поведінка стає не лише розумовою, а й моторною. При цьому, якщо контроль лише оцінює поведінку, то увага сприяє її поліпшенню [9].

Як зазначає П. Жане, регуляція поведінки пов'язана з організацією самої особистості. На його думку, існує сім рівнів регуляції, вищий 3 яких посідає система символічних механізмів, що перетворюють людину в активного діяча. Кожному з рівнів регуляції відповідає певний рівень усвідомлення, тому порушення поведінки є результатом зміщення вищих рівнів регуляції, що виявляється у вигляді сильних травмуючих переживань [7]. Крім того, П. Жане підкреслює значення символічних механізмів регуляції у подоланні травмуючих переживань: зняття фіксації на переживаннях відбувається внаслідок зміни його значення для індивідів.

Належний розвиток проблема символічної регуляції поведінки отримала у школах психоаналізу, гуманістичної психології та гештальтпсихології. Зокрема у психоаналізі Его людини розглянуто як символ, що регулює поведінку, підпорядковуючись принципу реальності на відміну від принципу задоволення. Саме символ покликаний реалізувати такі фу- 
нкції, як регуляція потягів, їх опосередкування, усвідомлення бажань, усвідомлення детермінованості своєї поведінки.

У регуляції та прогнозуванні поведінки Ж.П. Вірна важливу роль відводить трьом механізмам: самосвідомості, самооцінці та символові, вважаючи, що особистість діє відповідно до свого, символічного сприйняття подій, що відбуваються. Порушення поведінки є наслідком неузгодженості між самооцінкою та реальними життєвим досвідом людини, що проявляється у слабкій адаптованості до навколишнього світу, тривожності та напруженні. Відтворення здатності регулювати поведінку забезпечується символом, оскільки він розкриває сенс психічного явища, з яким взаємодіє особистість. Через те, що символ - згусток сенсу, заряджений нескінченною енергією, він здатен закликати особистість до дії, умотивовуючи іiі. Завдяки своїй енергії він спонукає, примушує, закликає й повеліває особистості діяти так, а не інакше [5].

За Л.С. Виготським, проблема регуляції поведінки особистості пов'язана зі створенням та використанням знакових психологічних знарядь, які він визначає як “оволодіння процесами власної поведінки”. У його концепції формування вищих психічних функцій визначається як функція відносно індивідуальної поведінки: певний нейтральний стимул лише тоді стає знаком, коли людина сама визнає його роль і функцію для себе, тобто надає йому функціонального значення і встановлює її ста- влення до вихідних мотивів поведінки [6].

Представники символічного інтеракціонізму підкреслюють, що регуляція поведінки особистості залежить від “символічного оточення” i “значущих символів”, - жесту і мови. Суспільну поведінку вони трактують як обмін жестами, що передбачає використання символів [10]. Розвиваючи ідеї символічного інтеракціонізму, Дж. Мід прагнув створити символічну теорію людської еволюції. Відповідаючи на питання, що відрізняє людину від тварини й що робить іï особистістю, Дж. Мід зазначає: “специфіка людини визначається відсутністю у неї розвинутої системи інстинктів як основних регуляторів поведінки. Саме тому людина має здатність винаходити символи, що є основою свідомого пристосування до навколишнього середовища, свідомої поведінки і самоспостереження" [10, с. 217]. Отже, головною характеристикою людської дії є використання символів.

На думку Дж. Міда існують такі форми (ступені) дії: 1) узагальнення за допомогою жестів; 2) символічно опосередковане спілкування. Спілкування за допомогою жестів відбувається за символічною схемою дії, яка дає змогу за окремим жестом відновити дію в цілому, а символічна регуляція поведінки породжує приблизно однакові реакції під час спілкування з будь-яким індивідом; дає змогу поставити себе на місце іншого; 3) дає змогу бачити себе очима іншої людини. Символічно опосередкована регуляція поведінки зумовле- 
на антропологічною здатністю особистості утворювати й використовувати символи для саморозуміння і планування власної поведінки.

\section{Висновки та перспективи подальших} розвідок у даному напрямі. Проведений аналіз зазначеної проблеми показав, що символ $\epsilon$ багатозначним регулятором відображення сучасного і майбутнього в поведінці особистості. Саме в символі міститься у згорнутому вигляді різноманітність значень поведінки особистості: смислових, інформаційних, прагматичних. Символ - це принцип побудови та регуляції поведінки особистості, першооснова початку певної ідеї, думки, яка переходить у дію; переконання, яким користується особистість, а також принцип подолання свавільної гри свідомості. Він дає змогу особистості скласти уявлення про свою поведінку, сформувати установку на дію.

Регулюючи поведінку, символ стає іï відображенням, законом, принципом і моделлю дії особистості. У символі як мовній, знаковій моделі дій над предметом міститься генетично вихідна інформація про дерево ознак - систему властивостей поведінки, яка ніби виростає з цієї моделі. Символ є функцією поведінки, яка дає змогу особистості всебічно пізнати себе.

Таким чином, регулюючи поведінку символом, особистість стає здатною самостійно конструювати й розробляти систему своїх розумових дій, контролювати їхній розвиток без перенавчання, не допускати стратегічних помилок. Наявність в образі псевдоінформації програмує дефект і людина виростає з неповноцінним механізмом.

\section{Перелік використаних джерел:}

1. Анохин П. К. Физиологическая архитектура эмоций и их место в развитии условных реакций / П. К. Анохин // Очерки по физиологии функциональных систем. - М. : Медицина, 1975. - С. 155-183.

2. Бернштейн Н. А. Очерки по физиологии движений и физиологии активности / Н.А. Бернштейн. - М. : Медицина, 1966. - 349 с.

3. Бехтерев В. М. Объективная психология / В. М. Бехтерев. - М. : Наука, 1991. - 480 с.

4. Валлон А. От действия к мысли / А. Валлон. - Издво : Директмедиа Паблишинг, - 2008. - 416 с.

5. Вірна Ж. П. Мотиваційно-смислова регуляція у професіоналізації психолога : [монографія] / Ж. П. Вірна. Луцьк : РВВ “Вежа” Волин. держ. ун-т ім. Лесі Українки, 2003. - 320 с.

6. Выготский Л. С. Психология развития человека / Л. С. Выготский. - М.: Изд-во Смысл; Эксмо, 2005. $1136 \mathrm{c}$.

7. Жане П. Психический автоматизм / П. Жане. - М. : Начало, 1913. - 455 с.

8. Клименко В. В. Психофізіологічні механізми праксису людини : [монографія] / В. В. Клименко. - К. : Видавничий Дім “Слово”, 2013. - 640 с.

9. Малхазов О.Р. Психофізіологічні механізми управління руховою діяльністю / О. Р. Малхазов. - К. : Свролінія, 2002. - 320 с.

10. Мид Дж. От жеста к символу / Дж. Мид // Американская социологическая мысль. - М. : Изд-во МГУ, 1994. - С. 215-224.

11. Павлов И. П. Лекции о работе больших полушарий головного мозга / И. П. Павлов. - М. : АН СССР, 1949. 
$-474 \mathrm{c}$.

12. Рубинштейн С.Л. Основы общей психологии / С. Л. Рубинштейн. - Изд-во : Питер, 2002. - 720 с.

13. Сеченов И. М. Элементы мысли / И. М. Сеченов // Избр. произв. : физиология и психология. - М., 1952. T. 1. - C. 272-427.

14. Соловйов О. В. Символ та мозок, або про те, як символ стає соціальним засобом узагальнення (частина 1) / О. В. Соловйов // Психологія. Зб. наук. праць НПУ ім. М.П. Драгоманова. - К., 2003. - Вип. 21. - С. 85-90.

\section{References (Transliteration):}

1. Anokhyn P. K. Fyzyolohycheskaia arkhytektura эmotsyi $\mathrm{y}$ ykh mesto $\mathrm{v}$ razvytyy uslovnukh reaktsyi / P. K. Anokhyn // Ocherky po fyzyolohyy funktsyonalnukh system. - M. : Medytsyna, 1975. - S. 155-183.

2. Bernshtein N. A. Ocherky po fyzyolohyy dvyzhenyi y fyzyolohyy aktyvnosty / N.A. Bernshtein. - M. : Medytsyna, 1966. - $349 \mathrm{~s}$.

3. Bekhterev V. M. Obiektyvnaia psykholohyia / V. M. Bekhterev. - M. : Nauka, 1991. - 480 s.

4. Vallon A. Ot deistvyia k musly / A. Vallon. - Yzd-vo : Dyrektmedya Pablyshynh, - 2008. - 416 s.

5. Virna Zh. P. Motyvatsiino-smyslova rehuliatsiia u profesionalizatsii psykholoha : [monohrafiia] / Zh. P. Virna. Lutsk : RVV "Vezha" Volyn. derzh. un-t im. Lesi Ukrainky, 2003. $-320 \mathrm{~s}$.

6. Vuhotskyi L. S. Psykholohyia razvytyia cheloveka / L. S. Vыhotskyi. - M.: Yzd-vo Smыsl; Эksmo, 2005. - 1136 s.

7. Zhane P. Psykhycheskyi avtomatyzm / P. Zhane. - M. : Nachalo, 1913. - $455 \mathrm{~s}$.

8. Klymenko $V$. V. Psykhofiziolohichni mekhanizmy praksysu liudyny : [monohrafiia] / V. V. Klymenko. - K. : Vydavnychyi Dim "Slovo", 2013. - 640 s.

9. Malkhazov O. R. Psykhofiziolohichni mekhanizmy upravlinnia rukhovoiu diialnistiu / O. R. Malkhazov. - K. : Yevroliniia, 2002. - $320 \mathrm{~s}$.

10. Myd Dzh. Ot zhesta k symvolu / Dzh. Myd // Amery- kanskaia sotsyolohycheskaia mыsl. - M. : Yzd-vo MHU, 1994. - S. 215-224.

11. Pavlov $Y$. P. Lektsyy o rabote bolshykh polusharyi holovnoho mozgha / Y. P. Pavlov. - M. : AN SSSR, 1949. $474 \mathrm{~s}$.

12. Rubynshtein S. L. Osnovu obshchei psykholohyy / S. L. Rubynshtein. - Yzd-vo : Pyter, 2002. - 720 s.

13. Sechenov Y. M. Elementu musly / Y. M. Sechenov // Yzbr. proyzv. : fyzyolohyia y psykholohyia. - M., 1952. T. 1. - S. 272-427.

14. Soloviov O. $V$. Symvol ta mozok, abo pro te, yak symvol staie sotsialnym zasobom uzahalnennia (chastyna 1) / O. V. Soloviov // Psykholohiia. Zb. nauk. prats NPU im. M.P. Drahomanova. - K., 2003. - Vyp. 21. - S. 85-90.

\section{Chmilar Oleg}

PhD, Associate professor, Department of Applied Psychology at H. S. Skovoroda Kharkov National Pedagogical University, Kharkov (Ukraine)

\section{THE REGULATION OF THE INDIVIDU- AL'S BEHAVIOR USING SYMBOL: THEO- RETICAL AND METHODOLOGICAL AS- PECTS}

\section{ABSTRACT}

The theoretical and methodological bases of the regulation of personality`s behavior using symbol, are viewed. By analyzing the approaches of home and foreign scholars, the authors haws the symbolic regulation as a function of the human psychology. The process of symbolic regulation is shown as the image of the internal goals of the individual. It is shown that the symbol, sets the individual's behavior in the desired direction, regulating it, because it can in fluency the process of thinking. It is shown how the person, by means 
of symbol, actualizes the meanings that are not understood in the rational iconic forms.

The symbolic methods of regulation of behavior are defined by the potential of the personality, cognitive attitude to himself and the ability to embody the thoughts, feelings and images in the form of objects. It was found that symbol - is a universal means of regulation of the spiritual and practical experience of the individual. It is a special image that provides regulation of individual's action sand deeds. The person reflects with the symbol the things, which are happening in her brain with the use of images.

Regulation of the behavior by means of symbol plays a special role in psychoanalysis, humanistic psychology and gestalt psychology, as it aims to regulate, train and motivate personality to do something. The symbol is a fundamental principle of regulating of the behavior of certain ideas, thoughts, which is then fulfilled. The symbol is regulation of an individual's behavior allows the person to put herself in the place of others in the process of interaction.

The role of symbol, as a function of behavior, that enables the individual to fully discover himself, was shown. It was found, that symbol, regulating the behavior, becomes its reflection, and also the law, principle and model of the action soft he individual.

Keywords: symbol, personality, regulator, action, symbolic regulation of the behavior.

\section{Хмиляр Олег Федорович}

Кандидат психологических наук, доиент, начальник кафедры общественных наук Начионального университета обороны Украины имени Ивана Черняховского, Киев (Украина)

\section{РЕГУЛЯЦИЯ ПОВЕДЕНИЯ ЛИЧНОСТИ СИМВОЛОМ: ТЕОРЕТИКО-МЕТОДОЛИЧЕСКИЙ АСПЕКТ}

Аннотация. Рассмотрены теоретикометодологические основы регуляции поведения личности с помощью символа. Показано, что символ, регулируя поведение личности, направляет его в желательном направлении, поскольку влияет на процессы мышления. Освещено как благодаря символу личность актуализирует смыслы, которые не осознаны в рационально знаковых формах.

Раскрыто роль символа как функции поведения, что позволяет личности всесторонне познать себя. Установлено, что символ, регулируя поведение, становится его отражением, законом, принципом и моделью действия личности.

Ключевые слова: символ, личность, регулятор, действие, символическая регуляция поведения. 